\title{
6
}

\section{Aesthetics and History:}

\section{L'Education sentimentale}

I'm having a lot of trouble linking my characters to the political events of 1848; I'm afraid the background will devour the foreground.

-Gustave Flaubert to Jules Duplan

The foregoing chapters have emphasized that aesthetics is a theory and an ideology of history, but so far the question of history has not achieved centrality. We have seen that the notion of the Bildungsroman is inherently historical insofar as it claims to represent or enact aesthetic pedagogy, since the temporal arc of the individual subject's Bildung always at least potentially exemplifies that of humanity. We have also seen, however, that the literary texts designated by the notion of the Bildungsroman destroy the aesthetic narratives they provide. They do not simply cast doubt on the rationale or the outcome of an aesthetic education; rather, they generate within the narrative of aesthetics allegories of its incoherent and uncontrollable production. The disruptive figural narratives we have encountered in variously innocent or sinister locales-a child's identification with marionettes in the Lehrjahre, a medical student's dissection of marionettes in the Wanderjahre, Madame Laure's murderous blow in Middlemarch-suggest that a "historicity" irreducible to representation inhabits aesthetic historicism, precisely because the latter ultimately has no choice but to seek to ground itself on the potential arbitrariness-the "literariness" - of language. ${ }^{1}$ It is now time to pursue that suggestion further by way of a text more consistently focused on the matter of revolutionary history.

Flaubert's L'Education sentimentale is useful territory on which to plot a conclusion to this study, since in addition to raising the question of the historical event, the text mercilessly exacerbates the negative spiral that seems to be the only condition of possibility of a Bildungsroman. Already in the Lehrjahre, as we saw, Bildung is recuperable, if at all, only as its own

1. See chapter 1 for a full account of the paradox of aesthetic formalism. 
negation; but in the case of Goethe's novel this insight required a degree of critical attention to obtain, while in that of $L^{\prime} E d u c a t i o n$ sentimentale it would add up to little more than a critical commonplace. The Bildungsroman may or may not exist, but one can at least be sure that Flaubert's novel will participate in this generic conundrum only as "an Unbildungsroman of genius." 2 Such negative certainty has its own seductions, of course. Since Flaubert's irony is neither sympathetic nor olympian in tenor, the aesthetic promise of his texts is all the more extreme, for the rigor of such obviously undeluded irony purges aesthetics of any lingering traces of idealist naiveté. When one adds to this rigor the pathos of a life dedicated to it, the result is a potent brew. It is no accident that over the course of the last century Flaubert has become a more genuinely international figure than Eliot or Goethe. "Flaubert seems very much at the source of a conception of the artist which is still with us," Jonathan Culler comments; ${ }^{3}$ and the historical success of this conception derives from its ability to link a valorization of the artwork's formal purity to a prurient obsession with the artist, or at the very least with the artist's self-sacrifice. The painful, sweaty, useless labor of writing; the blend of idealism, self-glamorization, and corrosive nihilism with which this labor is performed; the self-consumptive technologization of aesthetic composition such that writing becomes an endless askesis of rewriting, paring and deleting, asymptotically headed toward a "livre sur rien," or, in another famous formulation, toward a Book that "inasmuch as one separates oneself from it as author, does not require any approach by the reader" 4 -in short, the artist and the oeuvre of modernism. find their image in Flaubert, the "true Penelope" of more than one twentieth-century literary destiny or desire. Flaubert's name has come to signify the production and ratification of literature itself.

As a result, Flaubert-particularly the Flaubert of Madame Bovary-has become the object of fascinated scrutiny in a way few other cultural icons have. There is probably no real equivalent to Sartre's massive L'Idiot de la famille elsewhere in mainstream literary-critical discourse, nor is it easy to think of a novel that has inspired more whimsical metafiction than Madame Bovary. The lure of impersonality partly lies in our urge to violate it: to

\footnotetext{
2. Stirling Haig, Flaubert and the Gift of Speech: Dialog and Discourse in Four "Modern" Novels (Cambridge: Cambridge University Press, 1986), 159. An older school of criticism emphasized more positive links between Flaubert and the putative father of the Bildungsroman. Flaubert admired Goethe and refers to him frequently in his correspondence: details may be obtained in Léon Degoumois, Flaubert à l'école de Goethe (Geneva: Sonor, 1925); see also René Dumesnil, L'Education sentimentale de Gustave Flaubert (Paris: Nizet, 1963), 80-82.

3. Jonathan Culler, Flaubert: The Uses of Uncertainty, rev. ed. (Ithaca: Cornell University Press, [1974] 1985), 12.

4. Stéphane Mallarmé, Oeuvres complètes (Paris: Gallimard, 1945), 372.
} 
discover, whether in the name of existential analysis or metafictional play, a subject and a referential world behind the text's austere formal performance. ${ }^{5}$ And in addition to aggravating our desire for biography, the formal opacity of the fiction inspires the telling of another sort of ætiological narrative: in becoming the signatory of "literature," Flaubert becomes the origin of various and conflicting literary-historical developments-realism, modernism, "postmodernism." In all cases these narratives are characterized by a double figure of preservation and destruction: a name and a story link themselves to a vision of literature's emergence through its own self-obliteration. Flaubert's excision of "any novelistic element," Zola tells us, produces realism; his self-reflexive practice of citation, Michel Foucault claims, produces modernism- "Joyce, Roussel, Kafka, Pound, Borges. The library is on fire." 6 Thus, at one point in the writings of the most prominent Sartrean in Anglo-American criticism, Fredric Jameson, Flaubert becomes "the privileged locus" of a modernity "which the term reification in its strictest sense designates": "[T]he depersonalization of the text, the laundering of authorial intention, but also the disappearance from the horizon of its readership, which will become the public introuvable of modernism, are all so many features on which the process of reification feeds, using Flaubert's aesthetic vocation as its vehicle and mode of realization."7 Inherited from Lukács and Sartre, Jameson's model projects onto a historical axis the onto-theological patterns of the biographical and referential approach. At the origin, a closed communicative circuit returns meaning to a subject, while the fall into literature becomes an illegitimate descent into matter via the trope of "reification." Jameson's particular emphases in this passage are by no means determinative-at other points his dialectical model will valorize modernism differently-but Flaubert's appearance at this point in The Political Unconscious is not accidental and testifies to the ambivalence with which critics tend to express their fascination with the idea and practice of literature.

5. See Woody Allen's witty "The Kugelmass Episode," in Side Effects (New York: Random House, 1980), and Raymond Jean's less amusing Mademoiselle Bovary (Avignon: Actes Sud, 1991): both texts mobilize the conceit that Flaubert's novel is a world that can be entered, lived in, changed, and so on. An elegant and shrewd fictional meditation on Flaubert is Julian Barnes, Flaubert's Parrot (London: Jonathan Cape, 1984).

6. Emile Zola, Les Romanciers naturalistes (Paris: Charpentier, 1881), 125-26, cited in Jonathan Culler, "The Uses of Madame Bovary," in Flaubert and Postmodernism, ed. Naomi Schor and Henry F. Majewski (Lincoln: University of Nebraska Press, 1984), 1-12. For Flaubert as "postmodernist" see, of course, this collection. Michel Foucault's comments are directed at La Tentation de Saint Antoine: see "Fantasia of the Library," in Language, Countermemory, Practice: Selected Essays and Interviews by Michel Foucault, ed. Donald F. Bouchard, trans. Donald F. Bouchard and Sherry Simon (Ithaca: Cornell University Press, 1977), 92.

7. Fredric Jameson, The Political Unconscious: Narrative as a Socially Symbolic Act (Ithaca: Cornell University Press, 1981), 220-21. 
No text by Flaubert has been more frequently celebrated for its formal virtuosity or mined for its biographical content than $L^{\prime}$ Education sentimentale. 8 And as Jameson's comment makes clear, the question of Flaubert's formalism is bound up with the question of what history is. If history is the world's fall into capitalist reification, and if literature is a product and a mirror of that catastrophe, then the critic's recovery of a subject for the literary text-even the most negative, bored, self-hating subject-would function as a token of history's essential humanity. One may call such a hope "idealist," but it animates in covert fashion much of what counts as literary criticism, and it is not easy to avoid. $L^{\prime} E d u c a-$ tion sentimentale offers us the aesthetic in its most icily negative modeas the humanization, universalization, and, thus, the historical recuperation of the petty destiny of Frédéric Moreau via the askesis of pure form. Yet as Culler remarks, a "curious indeterminacy" has also been felt to be exerting pressure on the seemingly clear theme of "a Bildungsroman gone sour" (Flaubert, 135-36). In what follows I hope to show that this novel allows us to read the irreducibility of history to narrative, even the narrative of a catastrophe. Not for nothing is Frédéric's story that of ${ }_{1848}$, the revolution redux - the farcical reiteration of tragedy, as Marx famously put it, when "only the ghost [Gespenst] of the old revolution walked about." 9 Though L'Education sentimentale does narrate and scrutinize the story of reification that Jameson tells, the text also suggests the pertinence of Marx's spectral trope by exploring the possibility that uncanny, non-organic and non-aesthetic patterns of repetition compose the events we call historical.

\section{I}

The peculiar difficulties Flaubert's texts pose to interpretation are well known. Although the forms and conventions of nineteenth-century narrative remain in place, particularly in the "realist" novels Madame Bovary and L'Education sentimentale, the meaning of these forms is programmatically compromised, and at times radically shaken. The characters in L'Education sentimentale are coherent entities, and Frédéric is a psychologically nuanced one, but once we begin to read the text with care, the point of

8. For the canonical account of what used to be called "les protagonistes dans le roman et les personnages réels dans la vie," see Dumesnil's chapter of that title, in L'Education sentimentale de Gustave Flaubert, 15-78.

9. Karl Marx, The Eighteenth Brumaire of Louis Bonaparte (New York: International Publishers, 1963), 17. Subsequent quotations are to this edition; the translation has at times been silently modified with an eye to the German text in Karl Marx and Friedrich Engels, Werke (Berlin: Dietz Verlag, 1960), 8:115-207. 
these representations rapidly becomes dubious. Not only is Frédéric's a boring and mediocre consciousness, but the novel's interest in portraying this consciousness is somewhat sporadic, as though the text itself felt as a burden the monotony of its own unfolding. The things that happen to Frédéric fall short of significance, despite the perfectly conventionalwhich is to say, reasonably Balzacian-assembly of coincidences moving him through a relatively circumscribed field of characters and events. ${ }^{10} \mathrm{On}$ the face of it-though of course this is the question with which we are here proposing to dwell-neither his "sentimental education" nor his encounter with history in 1848 appears to add up to much. The former interferes with his experience of the latter but, as we shall see, fails to provide any secure locus of value. Meanwhile, though Frédéric himself at various points feels he has missed out on history because of his overinvestment in a bourgeois romance plot, the text suggests the inadequacy and bad faith of this reading as well, since his participation in the assault on the Tuileries leaves him with no clear psychological or symbolic profit. Neither the public world of revolution nor the private world of love offers any immediate justification for novelistic representation.

Furthermore, no uncompromised symbolic meaning takes up the slack. In this respect the problem of historical representation is exemplary: the main articulations of Frédéric's private life echo those of the historical narrative, but never quite allow the hero's education, or the failure of his education, to acquire the full dignity of a symbol.11 On the eve of the February uprisings, Frédéric fails to seduce Mme Arnoux but succeeds in getting her profane double, Rosanette, to take her place in his bed; on the eve of Louis Napoléon's coup d'état, witnessing the "vente de Mme Arnoux," Frédéric sees his ideal woman metaphorically dissolve into commodity exchange: these parallels—a second-best beginning; a sordid end-

10. The ways in which Flaubert mimes and undercuts the Balzacian novel have frequently been studied; for a recent analysis, see Peter Brooks, "Retrospective Lust, or Flaubert's Perversities," in Reading for the Plot: Design and Intention in Narrative (New York: Vintage, 1985), 171215.

11. The parallels are elaborate and carefully plotted: see Maria Amalia Cajuero-Roggero, "Diner chez les Dambreuses: 'La réaction commençante'," in Histoire et langage dans ' $L$ 'Education sentimentale' de Flaubert (Paris: Société d'édition d'enseignement supérieur, 1981), 63-76, and Anne Herschberg-Pierrot, "Le travail des stéréotypes dans les brouillons de la 'prise des Tuileries'," 43-61, in the same collection. As Cajuero-Roggero shows, manuscript versions of $L^{\prime}$ Education sentimentale make clear that the dinner at the Dambreuses takes place on 2 July, which is when the forces of reaction gained visibility when Cavaignac reviewed his troops at the Concorde; similarly, Dussardier is killed on the day when, according to Flaubert's notes, popular resistance was definitively crushed. Flaubert suppressed or camouflaged his array of significant dates in the final version of the manuscript. Herschberg-Pierrot's study recovers several intriguing examples: the "prise des Tuileries" is carefully dated ${ }_{24}$ February in an early manuscript; and Frédéric and Rosanette leave for Fontainebleau on the 2oth of June. 
offer the teasing possibility of a symbolic structure, but one is also left with a sense that the interpretation has succeeded only at the cost of missing the point. Textual elements that ought to be symbolic raise problems that nag at the reading mind: Rosanette's diseased and short-lived baby, for instance, should be an embodiment of historical decay, but the dates of its conception and birth do not quite match any date of political significance, and one is left either with a handful of loose ends or with the weaker and more gratuitous claim that the infant embodies belatedness, sterility, insignificance, and so on. The transformation of Arnoux's periodical and art gallery $L^{\prime}$ Art industriel into an earthenware factory and, finally, a trade in religious artefacts suggests, like the "vente" of Mme Arnoux, a certain degradation, an increasing triumph of the commodity; so does Frédéric's acquisition of a second mistress, the moneyed Mme Dambreuse, at the beginning of part 3; but the categories needed to organize these events into a meaningful pattern are sufficiently large and vague as to seem slightly otiose. Things get even worse if we abandon the historical dimension and begin portioning out the binary oppositions of literary and theological tradition. Mme Arnoux and Rosanette may be linked and opposed as the ideal and the actual, spirit and flesh, sacred and profane, and so on; with the arrival of Mme Dambreuse the lure of the profane becomes that of avaritia as well as voluptas; these and other allegories spin easily out of Frédéric's story, and in their overscripted facility announce themselves as received ideas, the hermeneutic equivalent of Arnoux's commodified icons. Anything can and must be interpreted in this textual world, but the resultant meanings come accompanied by a faint or glaring aura of bêtise.

Yet even that generalization is insufficiently guarded, for at times Flaubert's text will achieve a density such that one cannot be sure whether one is trapped within an ironic structure or not. In the great final scene between Frédéric and Mme Arnoux, for instance, the text blends ironic distance with dramatic intensity such that the status of phrases such as Mme Arnoux's famous future anterior "nous nous serons bien aimés" becomes impossible to decide. 12 The scene is genuinely moving, and draws on the memory of other moments of intensity in the history of Frédéric and Mme Arnoux's star-crossed love; yet the future anterior assertion-we will have loved: in a time not yet present, our love will be past; our love is fiction, the affirmation of an imagined memory-manages to be at once

12. Gustave Flaubert, L'Education sentimentale, in Oeuvres complètes (Paris: Club de l'Honnête Homme, 1971-75), 3:394. Subsequent references are to this edition; English translations have been taken from Sentimental Education, trans. Robert Baldick (Harmondsworth: Penguin, 1964), but have frequently had to be revised: Baldick's translation of Mme Arnoux's phrase, for instance, "we have loved each other well" (413), misses the whole point of the phrase by ignoring Flaubert's future anterior ("we will have loved"). Double page numbers refer to the French and English editions respectively. 
delicately affirmative and naggingly deluded. The fragile and radical fictionality of love occurs as a citation that, in marking its fictional status, falls short of itself, while retaining its pathos:

"Sometimes your words come back to me like a distant echo, like the sound of a bell carried by the wind; and I feel you are there, when I read about love in books."

"Everything one criticizes as exaggerated in books, you have made me feel," said Frédéric. "I can understand Werther not being put off by Charlotte's bread and butter." (393-44/413)

Even the slightly comic reference to Werther, of all texts, does not strip the passage of its force; yet at the same time, if Frédéric and Mme Arnoux can express themselves only through literary language, the ethical and libidinal correlatives to this predicament create an uncertain hovering between authenticity and bad faith. Shocked by her age, Frédéric pours out his love "to conceal from her his disappointment," and falls into his own illusion: "She rapturously accepted this adoration of the woman she no longer was. Frédéric, drunk on his own words, began to believe what he was saying" (394/414). The scene builds toward an elegant and merciless paragraph:

Frédéric suspected Madame Arnoux of having come to offer herself; and he was seized by a desire [convoitise] stronger than ever, frenzied, rabid. Yet he also felt something else, an indefinable feeling, a repulsion, like the dread of incest. Another fear stopped him, that of being disgusted later. Besides, what a nuisance it would be! And partly out of prudence and partly to avoid degrading his ideal, he turned on his heel and started rolling a cigarette. $(395 / 415)$

The slippage of love's literary language into the blend of passion and calculation of a "convoitise"; the careful splicing of motive such that Frédéric's archaic fear of incest becomes no more and no less compelling than his worry about an awkward entanglement; the coolly incisive summation of his turn away from Mme Arnoux, "tout à la fois par prudence et pour ne pas dégrader son idéal" —all this psychological fretwork shows Flaubert a master of literary realism and as such presents no difficulty; however, over the course of this scene the trope of "love" becomes illegibly poised between irony and affirmation. Read figuratively, as its own ironic negation, love provides a certain bleak knowledge: the sentimental education will at least have been able to confirm the essential falseness of love. Read literally, as an affirmation of itself, love offers us the delicate integrity of fiction ("nous nous serons bien aimés") but makes the sentimental education irrelevant, since the pure fictionality of this love's temporal structure has noth- 
ing to do with the accretive temporality of experience, being spun out of a grammatical subject's ability to be at once future and past. ${ }^{13}$ Both of these alternatives have their seductions and drawbacks, but both exist only insofar as they destroy each other's possibility. It is impossible to say whether love should be read literally or as a self-consuming figure, and it is also impossible for the characters to remain suspended between these two alternatives, or securely ensconced in one of them. They know their fictionality yet they believe their own words, and in both cases they are at once justified and deluded.

At moments like these the text pushes to the limit our ability to read its irony. On the one hand, the novel has served us an illegible figure; on the other hand, in saying this we are also always saying that the text has intended to be illegible, and in Flaubert's case, of course, we can promptly beef up textual with authorial intent. His famous poetics of citationality has succeeded: doxa has been parroted with such elegant cunning that the reader cannot tell whether the performance is a parody or not. ${ }^{14}$ Even as we state our uncertainty, we obliterate it by recanonizing text and author. When Roland Barthes, for instance, tells us that in Flaubert's case "one never knows if he is responsible for what he writes (if there is a subject behind his language)," he is also inevitably telling us that Flaubert has accomplished this uncertainty, and, indeed, should be given credit for having done so. ${ }^{15}$ But the linguistic structures making possible le Garçon's last and most subtle joke are indeed not necessarily under subjective control, for precisely the reasons Flaubert suggests in staging Frédéric and Mme Arnoux's last encounter. If we unmask fiction as merely fictional we thereby tumble into believing it; yet as soon as we start believing in it-by crediting Flaubert or Flaubert's text, for instance, with the knowledge of its own unknowability-we are as deluded as Frédéric, swept away by his own rhetoric of love. For whatever the historical Flaubert may have intended or known, the authoritative Flaubert one constructs while reading $L^{\prime} E d u c a t i o n$ sentimentale is an irreducibly literary fantasy, projected onto a

13. A point made by Victor Brombert in " $L$ 'Education sentimentale: Articulations et polyvalence," in La production du sens chez Flaubert: Colloque de Cerisy (Paris: 10/ 18, 1975), 66-68, and by Culler, Flaubert, 151-56. Culler's emphasis falls on the "fragile romantic triumph" this scene provides, as well as on the fact that the detached fictionality of this romantic triumph "makes nonsense" out of "the explicit contrasts in terms of which the rest of the book appears to be constructed" (155).

14. There are many fine studies of Flaubert's techniques of citation and defamiliarization: the best is still Culler, Flaubert, esp. 75-156; see also Christopher Prendergast, "Flaubert and the Stupidity of Mimesis," in The Order of Mimesis: Balzac, Stendhal, Nerval, Flaubert (Cambridge: Cambridge University Press, 1986), 180-211. For a close study of Flaubert's subversive use of free indirect style (such that one cannot tell what degree of authority to grant utterances, etc.), see Claude Perruchot, "Le style indirect libre et la question du sujet dans Madame Bovary," in La Production du sens chez Flaubert, 253-74.

15. Roland Barthes, S/Z, trans. Richard Miller (New York: Hill and Wang, 1974), 140. 
textual aporia. The result, as we have seen, is a highly successful, because profoundly ambivalent, canonization of Flaubert. We read an overabundance of meaning into his work in order to evade the difficulty of reading it-a difficulty that manifests itself in the preprofessional era of Flaubert studies as a condemnation of the textual nihilism one now so easily recuperates. "L'Education," Thibaudet commented in the 1930s, "was immediately and is still today criticized for taking part itself, as a work of art, in this wastage, this emptiness, this bankruptcy."16 One often speaks a little too easily of Flaubert's valorization of form. The "continual, monotonal, sad, indefinite procession" of his prose, as Proust famously described it, marks a habit of writing irreducible even to the negative aesthetics it propagates. ${ }^{17}$

It is no accident that in the closing pages of $L^{\prime} E d u c a t i o n$ the figure of "love" should organize the text's resistance to understanding. Love not only stages the question of Bildung in this text, but the double-edged lure of literature itself. Nothing is more stereotyped than love, yet love alone has the power to forget its own banality. Love is the force of fiction, a force that, for all its power to shape lives and events, may only exist because we read about it in novels: this is the idée reçue providing what Michael Riffaterre would call the matrix or hypogram for the erotic destinies of Emma in Madame Bovary and Frédéric in L'Education sentimentale. ${ }^{18}$ We may note in passing that one consequence of this literary problematic is the peculiarly atavistic forms that desire so frequently assumes in Flaubert-the odd slippage between realism and allegory, for instance, that causes Emma Bovary to be "burnt more fiercely by that intimate flame which her adultery kept feeding, panting and overcome with desire," as though the ancient figure of adultery, not the consciousness of a young bourgeoise, were desire's true subject. ${ }^{19}$ The slightly archaic ring of Frédéric's "convoitise"

16. Albert Thibaudet, Gustave Flaubert (Paris: Gallimard, 1935), 150; cited in Culler, Flaubert, 149.

17. Marcel Proust, "A propos du 'style' de Flaubert," in Chroniques (Paris: Gallimard, 1927), 194 .

18. See Michael Riffaterre, “Flaubert's Presuppositions," in Flaubert and Postmodernism, 177-91; for a more general elaboration of Riffaterre's terminology, see his Text Production, trans. Terese Lyons (New York: Columbia University Press, 1983).

19. Gustave Flaubert, Madame Bovary, ed. and trans. Paul de Man (New York: Norton, 1965), 210; for the French see Madame Bovary: Moeurs de province (Paris: Club de l'Honnête Homme, 1971-75): "brûlée plus fort par cette flamme intime que l'adultère avivait, haletante, émue, tout en désir . .." (307). One of Flaubert's more remarkable descriptions of desire was excised from the final version of Madame Bovary: when Charles, after Emma's death, meets Rodolphe and pronounces his grand mot ("It was the fault of fate"), Rodolphe, who had had a hand in this fate, finds the remark "comic and slightly despicable": "For he understood nothing of that voracious love which hurls itself at random on things to slake itself, of that passion empty of pride, without human respect or consciousness, which plunges entirely into the loved object, seizes its sentiments, palpitates with them, and nearly attains the proportions of a pure idea, through its size and impersonality." Madame Bovary, nouvelle version, précédée des scenarios inédits, ed. J. Pommier and G. Leleu (Paris, Corti, 1949), 641. 
serves in similar fashion to denaturalize his lust and attach it to a rhetoric of transgressive love that has no securable tie to the realist worlds in which he or Emma move. Love is literary to the extent that its power is undecidably that of myth or of cliché.

But the aporia of love does not exhaust the literary problematic staged by L'Education sentimentale; we have yet to approach the text's central crux, which is the relation between "love" and "history." The path I propose to follow at this point has been marked out by Flaubert's reception. Particularly in the wake of Sartre's L'Idiot de la famille, critics have frequently construed Flaubert's texts in terms of linguistic, libidinal, or socioideological fetishism. ${ }^{20}$ To such construals the texts respond with such alacrity that a closer look at the notion of the fetish holds considerable promise. Our brief examination of the scene between Frédéric and Mme Arnoux has already made it obvious that in L'Education the conundrum of love is male; and besides marking the institution of sexual difference, the notion of fetishism will eventually help us sketch a relation between the aporetic figure of love and the revolutionary event it appears to foreclose.

I I

What is a fetish? A dazzling apparition, self-originary and unique; a secret embodiment of sight itself:

It was like a vision [Ce fut comme une apparition]:

She was sitting in the middle of the bench, all alone; or at least he could not see anybody else in the dazzling light [éblouissement] which her eyes cast upon him. (L'Education, 50/18)

From the impersonal, gender-neutral demonstrative pronoun "ce," the passage fans out into the epiphanic primal scene of the male subject's love plot, as though both this subject and his fetish were simultaneously struck into existence-or indeed, as though the fetish emerged before the subject, rupturing the "sad indefinite procession" of Flaubertian prose in order to generate in its own ravishing gaze the possibility of the subject's. A hyperbolic, even hallucinogenic moment of privacy secretes this subject: the fetish exists only for him, and likewise he exists only for "her" ("or at least he could not see anybody else in the dazzling light which her eyes cast upon him").

20. Numerous studies of recent date touch on the question of fetishism in Flaubert; see in particular Charles Bernheimer's discussion of Bouvard et Pécuchet in Flaubert and Kafka: Studies in Psychopoetic Structure (New Haven: Yale University Press, 1982), 102-38, and above all Tony Tanner's discussion of Madame Bovary in Adultery and the Novel: Contract and Transgression (Baltimore: Johns Hopkins University Press, 1979), 233-367. 
The wishfulness of this scenario shows up in the hint of uncertainty coloring the act of exclusion out of which male subject and female object emerge ("or at least ..."); and the glory of the fetish resides in its ability to transform this uncertainty into the pleasurable pain of the sublime. "Her" gaze gives "him" sight as and through blindness (éblouissement), at the same time that she herself assumes the blindness of the object: her eyes cast light, but do not see. The oedipal threat, minimally registered here as the ideal object's power to blind, launches the subject of desire into its narrative of loss and substitution. Pushing further, one might venture the claim that the fetish's éblouissement provides a mythical, Medusa-esque origin for the story of the subject's eventual reification-an origin that we saw Fredric Jameson fetishistically locating in the event of Flaubert.

What, then, is a fetish? A dazzlingly overdetermined locus of speculation, knotting questions of language, religion, commerce, and desire. The word returns etymologically to artifice or representation (facticius) by way of the Portuguese feitiço. Originally signifying a token on which traders took oaths to ratify commercial treaties on the African coast, the word feitiço entered general European discourse at the end of the eighteenth century in association with the religious practices of the "primitive" cultures Europe was engaged in colonizing. ${ }^{21}$ In its "origins," then, the fetish marks and guarantees the occurrence of discourse. It records the event of an oath or promise, underwriting the oath's performative force, and thereby securing commercial transactions. The fetish guarantees the promise that goods will circulate by recording the circulation of language and desire. It performs, as it were, the power of the performative and thereby draws on the arbitrary (and "primitive") force of the divine. This densely linguistic dimension of the fetish grants it great theoretical power. Though the Freudian and the Marxist appropriations of this term to some extent move in opposite directions - the former conceiving it as a palliative for loss, and the latter as an occlusion of labor-both draw on the fetish as a figure for illusory authority, and both elaborate this figure into a story of the production of a subject of desire.

Marx's brief discussion of commodity fetishism in Capital has frequently provided a springboard for sophisticated Marxist definitions of "ideology," because the fetishism Marx discovers in the commodity inheres in the process of production rather than in the deluded consciousness of the con-

21. For a history of the term "fetish" see William Pietz, "The Problem of the Fetish," parts 1, 2, and 3, in Res 9 (1985): 5-17, Res 13 (1987): 23-45, and Res 16 (1988): 105-23. See also Pietz, "Fetishism and Materialism: The Limits of Theory in Marx," in Fetishism as Cultural Discourse, ed. Emily Apter and William Pietz (Ithaca: Cornell University Press, 1993), 119-51, esp. 129-40, for a discussion of the term's appearance in late eighteenth-century theory and history of religion, its importance in Comte's positivist system (as the "first theological phase"), in nineteenth-century anthropological writing, and so on. 
sumer. "A commodity," Marx writes, "appears at first sight an extremely obvious, trivial thing. But its analysis brings out that it is a very strange thing. . . . [A]s soon as it emerges as a commodity, it changes into a sensible suprasensible thing [ein sinnlich übersinnliches Ding]."22 The commodity generates the fetishistic illusion that value inheres in it as an object of exchange: an illusion that Marx represents as a process of personification and reification. A piece of wood, turned into a table turned into a commodity, "evolves out of its wooden brain grotesque ideas," and this life of the commodity springs from the reifying dynamic of commodity production itself: "The mysterious character of the commodity-form consists therefore simply in the fact that the commodity reflects the social characteristics of men's own labour as objective characteristics of the products of labour themselves.... Through this substitution, the products of labour become commodities, sensuous things which are at the same time suprasensible or social" (Marx, Capital, 164-55). Crucial to Marx's insight, though occasionally overlooked in marxist theory, is his understanding of the commodity as both a rhetorical entity and an economic entity. Socially organized human labor produces it, but it becomes a commodity, a "sensible supersensible thing," only through the chiasmic exchange of properties between person and thing. ${ }^{23}$ Self-obfuscation inheres in the production of the commodity. This excess of production also implies that in coming into existence the commodity generates a desire for itself over and above whatever attraction it might possess as a mere object. Commodity fetishism may thus be said to produce for capitalism a desiring subject-a subject that finds its epitome in the capitalist, whose unending desire to accumulate wealth derives from the personification of structural relations: "[I]t is only insofar as the appropriation of ever more wealth in the abstract is the sole driving force behind his operations that he functions as a capitalist, i.e., as

22. Karl Marx, Capital trans. Ben Fowkes (New York: Vintage, 1977), 1:163, translation modified; for the German, see Das Kapital, in Karl Marx and Friedrich Engels, Werke, $23: 85$.

23. This exchange of properties consequently poses a problem of reading: "Value, therefore, does not have its description branded on its forehead; it rather transforms every product of labour into a social hieroglyphic. Later on, men try to decipher the hieroglyphic" (Marx, Capital, 167). Close readings of Capital have drawn attention to the rhetorical complexity of the commodity form in Marx's analysis: see especially Thomas Keenan, "The Point Is to (Ex)Change It: Reading Capital, Rhetorically," in Fetishism as Cultural Discourse, ed. Apter and Pietz, 152-85. Keenan examines the figure of "abstraction" that transforms use value-which is always absolutely particular-into exchange value. This violent and impossible abstraction leaves as a "residue" a "ghostly objectivity [gespenstige Gegenständlichkeit]" (Marx, Capital, 128), the "residue of the abstraction itself" (Keenan, "The Point Is to (Ex)change It," 169). The play of ghosts in Marx's text has also been analyzed by Jacques Derrida, in his Spectres de Marx: L'Etat de la dette, le travail du deuil et la nouvelle Internationale (Paris: Galilée, 1993): see 246-79 for a discussion of Marx's example of the table. The difficult figure of "use value" in Capital is analyzed in Gayatri Chakravorty Spivak, "Scattered Speculations on the Question of Value," in her In Other Worlds (New York: Routledge, 1988), 154-75. 
capital personified and endowed with consciousness and a will" (Capital, 254). The odd, impersonal quality of desire in Flaubert, a blend of passivity and insatiability that we earlier attached to allegorical language, may thus also be represented in terms of the personifying force of commodity exchange: capitalism is in this sense the ferocious accomplishment of allegory.

Freud's more systematic rewriting of the notion of fetishism overtly locates the fetish at the origin of the subject's production as a subject of desire, and thereby develops a complex understanding of the fetish's rhetorical character. As a substitute for the missing maternal phallus, the fetish in Freud is a radical fiction, and is compounded of seemingly contradictory qualities: it provides pleasure and consolation only and precisely to the extent that it memorializes a trauma. The (male) subject, reading its own possibility in the mirror of the mother's lack, papers over this absence with a substitute object; the subject's "interest" in this fictional penis then "suffers an extraordinary increase" precisely because "the horror of castration has set up a memorial [Denkmal] to itself in the creation of this substitute."24 Freud's analysis of the Medusa's head is perhaps his most evocative account of the fetish's ability to eroticize trauma by representing it. Since "to decapitate" is "to castrate," the terror of Medusa is "a terror of castration that is linked to the sight of something" - the female genitals, and "essentially those of [the] mother." 25 The snakes on the Medusa's head symbolically threaten the male viewer since they recall the pubic hair surrounding the "castrated" maternal genitals; however, they also, simultaneously, "serve as a mitigation of the horror, for they replace the penis, the absence of which is the cause of the horror." Even the Medusa's power to petrify the male observer is paradoxically consoling: "For becoming stiff means an erection. Thus in the original situation it offers consolation to the spectator: he is still in possession of a penis, and the stiffening reassures him of the fact." The fetish is apotropaic because it represents the subject's annihilation to the subject, which can thereby persuade itself of its own existence.

Freud's schema yields a further refinement: as in Frédéric's first vision of Mme Arnoux, the fetish may be understood as the occlusion not of lack but of uncertainty. It requires an act of interpretation, after all, to see a lack, particularly a lack taken as the antonym-and the potential destiny, or deeper reality-of a penis's presence. The maternal phallus would thus be a fiction erected not over a void but over illegibility. Freud registered this dimension of the fetish in epistemological terms as the mechanism of

24. Sigmund Freud, "Fetishism," in The Pelican Freud Library, vol. 7: On Sexuality: Three Essays on the Theory of Sexuality and Other Works, ed. Angela Richards, trans. James Strachey (Harmondsworth: Penguin, 1977), 353.

25. Sigmund Freud, "Medusa's Head," in Collected Papers, ed. James Strachey (London: Hogarth Press, 1950), 5:105. 
disavowal whereby the mother's "castration" is at once accepted and denied: the child believes and disbelieves, and the ego splits around this double bind. ("The whole process seems so strange to us," Freud comments dryly in a posthumous fragment, "because we take for granted the synthetic nature of the processes of the ego. But we are clearly at fault in this." $)^{26}$ Thus, despite its overwhelmingly visual ætiology in Freud, the fetish must in a sense be understood as prior to and productive of sight rather than the product of it. The terrifying "sight of something" has to be read as "something" to see before it can be "seen." One may thus speak of a fetishism at the origin of perception itself.

In L'Education sentimentale the dynamic of fetishism inheres in the production of subject and text, conditioning all forms of semiotic, economic, and libidinal circulation in the "capital of the nineteenth century" in which Frédéric loves and shops. ${ }^{27}$ Desire is the desire of the commodity, and of the maternal and feminine as commodity; yet if desire and its representation express themselves through commodities, commodities, under the pressure of so much desire, become tokens of an inarticulate madness in the same way that Flaubert's text does. Whatever the cultural and socioeconomic codes mobilized, for instance, when Arnoux marches into the narrative line shod in "strange red boots, of Russian leather, decorated with blue patterns" (L'Education, 48/16), the objects in question-minuscule versions of Charles's cap in Madame Bovary - linger subtly past meaning, the occasion of an odd, empty astonishment and the product of a pointless and unstoppable fetishism. The self-annihilating aesthetic of the artwork, in this scenario, comes to coincide with the most degraded sort of sublimity-or vice versa: it would be equally accurate to say that Arnoux's boots or Charles's cap acquire the idiotic pointlessness of the artwork. The degradation of Arnoux's L'Art industriel into a ceramics factory and a trade in religious kitsch may be read as one of the many jokes the text makes at the expense of its own aestheticism, not to mention its future canonization.

As an essential part of its fetishistic project, Flaubert's text mirrors Frédéric's desire in funneling the polyvalent intensities and uncertainties of the fetish into the figure of Mme Arnoux. In her case we may indeed say that fetishism inheres in perception itself-so much so that Frédéric can construct memories of her that are more detailed than his initial perception

26. Sigmund Freud, "Splitting of the Ego in the Process of Defense," in The Pelican Freud Library, vol. 11: On Metapsychology: The Theory of Psychoanalysis, ed. Angela Richards, trans. James Strachey (Harmondsworth: Penguin, 1984), 462.

27. Walter Benjamin, "Paris: Capital of the Nineteenth Century," in Reflections, trans. Edmund Jephkott (New York: Schocken Books, 1978), 146-62: see in particular his comments on the erotics of "fashion": "It couples the living body to the inorganic world. Against the living it asserts the rights of the corpse. Fetishism, which is subject to the sex appeal of the inorganic, is its vital nerve" (153). 
of her is: "[T]he whole of his journey on the boat came back to his mind so clearly that he could now remember fresh details, more intimate particulars: her foot, in a brown silk boot, peeping out under the lowest flounce of her dress, the drill awning forming a wide canopy over her head, and the little red tassles on the fringe trembling perpetually in the breeze" $(53 / 22)$. As the fetish of fetishes, Mme Arnoux herself is unobtainable-in a Lacanian spirit one could say that she doesn't exist-and the objects that substitute for her meet Frédéric's desire with the arbitrary convenience of commodities in a shopping gallery. Though it is true that over the course of the narrative he pays particular homage to Mme Arnoux's feet, the other treasured objects of his gaze-her umbrella, her basket, pieces of clothing-are so numerous and so democratically invested with significance that the integrity of the fetish immediately finds itself compromised. ${ }^{28}$ In fetishism, as Emily Apter observes, "a consistent displacing of reference occurs, paradoxically, as a result of so much fixing." 29 Mme Arnoux's dispersal inheres in her fetishization; only the pathos of repetition separates the beginning of the sentimental education from its end in the "vente de Mme Arnoux," when the fetish is scattered into memorials to be mourned in the sonorous rhythms of an extreme unction:

In this way there vanished, one after another, the big blue carpet with its pattern of camellias which her dainty feet used to touch lightly as they came toward him; the little tapestry easy-chair in which he always used to sit facing her when they were alone; the two fire-screens, whose ivory had been made smoother by the touch of her hands; and a velvet pincushion, still bristling with pins. He felt as if a part of his heart were disappearing with each article; and the monotonous effect of the same voices accompanied by the same gestures numbed him with fatigue, afflicting him with a deathly torpor, a sense of disintegration. $(387-88 / 407)^{30}$

The very force unifying Mme Arnoux into "the point of light on which all things converged" (53/22) scatters her into a litany of coveted detail; and the self that reads its identity in Mme Arnoux eventually finds itself

28. The arbitrary, metonymic quality of Frédéric's fetishism is examined in Maureen Jameson, "Métonymie et trahison dans L'Education sentimentale," Nineteenth-Century French Studies 19.4 (1991): 566-82; see also Michal Peled Ginsburg, Flaubert Writing: A Study in Narrative Strategies (Stanford: Stanford University Press, 1986), 132-53: “Dussardier and Madame Arnoux are indeed ideal mirror images, marked by purity, unity, and stability; but the qualities that make them into ideal mirror images are produced arbitrarily and contingently, and this fact undermines the very notion of ideal mirror image" (148).

29. Emily Apter, Introduction to Fetishism as Cultural Discourse, 3.

30. Brooks (Reading for the Plot, 205) notes and discusses the fact that these sentences echo those describing Emma Bovary's extreme unction: compare Madame Bovary, 335/237. 
"numbed" by "the monotonous effect of the same voices accompanied by the same gestures." This numbness, fatigue, and disintegration recall the problems and seductions of literary language, since the "monotonous effect" of the auctioneers' gestures and voices is teasingly similar to the iterative splendor of the famous Flaubertian imperfect ("que ses pieds mignons frôlaient . . ."; "où il s'asseyait toujours ... ."). ${ }^{31}$ If Mme Arnoux "resemble[s] the women of romantic novels" (53/22), her lover, appropriately, resembles a frenzied connoisseur: "He knew the shape of each of her nails; he delighted in listening to the rustle of her silk dress when she passed through doors; he furtively sniffed at the scent on her handkerchief; her comb, her gloves, her rings were things of special significance to him, as important as works of art, almost animated like people; they all took possession of his heart and strengthened his passion" (92/66, emphasis added). The fetish of fetishes is the artwork and the woman as artwork: the "point lumineux" of Mme Arnoux that substitutes itself for the Virgin, the phallus, and the aesthetic symbol, and simultaneously disappears into the anonymity of exchange.

It is in this matrix of fetishism that the text's articulation of "love" and "history" will need to be sought. Yet first we may briefly observe that the very omnipresence of fetishism in this novel renders legibly arbitrary and overdetermined the text's repetition of Frédéric's fetishization of Mme Arnoux. Though $L^{\prime} E d u c a t i o n$ sentimentale certainly leaves little space for any very satisfying feminine subject position, ${ }^{32}$ the novel may at least be said to demonstrate the inextricability of aesthetic history, phallocentrism, and commodification, and to suggest that only the contingency of artifice, facticius, determines this tradition's erection of the maternal phallus as a figure for its fears and desires. A radical critique of this sort has its practical uses. Flaubert's texts at once predict and demystify the reactive gesture of a

31. More violent, punctual instances of the fetish's fragmenting power also occur in the text. After Rosanette's appearance at the beginning of the second part of the novel, Frédéric dreams of being raped and castrated by her, after seeing dismembered pieces of women pass back and forth: "[I]n the hallucination of his first sleep he saw passing to and fro before him the Fishwife's shoulders, the Stevedore's back, the Polish girl's calves, and the Savage Woman's hair. Then two big dark eyes [i.e., Mme Arnoux's], which were not at the ball, appeared; and light as butterflies, bright as torches, they darted here and there, quivered, flew up to the ceiling, then swooped down to his lips. Frédéric struggled to recognize those eyes, without success. But already a dream had taken hold of him; he thought he was harnessed side by side with Arnoux in the shafts of a cab, and the Marshal, sitting astride him, was tearing his belly open with her golden spurs" (L'Education, 152/134). The more irresolute passages we are focusing on may be read as counterweights to such aggressively focused, oedipal scenarios.

32. See L. Czyba, Mythes et idéologie de la Femme dans les romans de Flaubert (Lyon: Presses Universitaires de Lyon, 1983), for a study of the misogynistic stereotypes at work both in Flaubert's texts and in French culture from the July Monarchy and the 1848 Revolution through the $1870 \mathrm{~s}$. Czyba points out that $L^{\prime} E d u c a t i o n$ sentimentale (mis)represents the 1848 Revolution as an exclusively male affair, barring figures of satire such as Mlle Vatnaz. 
reader such as Jean-Paul Sartre, who, seeking to bring the "derealized" language of the Flaubertian text back to the certainties of experience, seizes upon a maternal scapegoat: "Flaubert's fetishism is the result and the summation of his sexual unrealizations, and these cannot be understood apart from the original derealization. His mother, male impersonator by imposture, woman by betrayal, constituted him such that he never stopped demanding from her a form of sexual retotalization that she had denied him from the cradle, and subsequently revealed herself incapable by nature of giving him." 33 Everything finally returns to nature, thanks to the motherand it is her fault to boot: the mother represents at once "nature" and nature's lack or insufficiency. She is the ground of language, and her crime consists in ungrounding it. The fetishistic character of Sartre's argument is all the more striking in that he is basing it on a confessedly baseless fantasy: "The truth of this reconstruction cannot be proved; its likelihood is not measurable" (1:56); "This is a fabrication, I confess. I have no proof that it was so" (1:139). But soon enough the fantasy turns into fact: "It was his mother's pious and glacial zeal that constituted Gustave a passive agent; Mme Flaubert was the source of this 'nature' and the malaise through which it was expressed" (1:180). The energy with which Sartre repeats Frédéric's discovery of the oedipal radiance of a maternal Mme Arnoux responds to a literary insistence that exceeds and undermines the very fetish it composes. As always within the orbit of aesthetics, the uncertain status of language is a political issue, a matter for the paterfamilias, if not, indeed, for the police. ${ }^{34}$

33. Jean-Paul Sartre, The Family Idiot: Gustave Flaubert, 1821-1857, trans. Carol Cosman (Chicago: University of Chicago Press, 1981), 2:67. In the original French version the quotation comes from volume 1: see L'Idiot de la famille: Gustave Flaubert de 1821 à 1857 (Paris: Gallimard, 1971), 1:719-20. The emphasis on "by nature" in this passage is Sartre's.

34. Flaubert's densely textured critique of the presuppositions at work in Sartre's fantasy is particularly visible early in the novel when Frédéric reads the words "Jacques Arnoux" on a marble plaque and thinks of "elle" (L'Education, 62-63/32)-Mme Arnoux, of course, though grammatically the pronoun also applies to the "plaque de marbre" on which the paternal name (which also here signifies the commercial entity L'Art industriel) is inscribed. A few pages later Frédéric's fetishization of this signifier becomes more pronounced: “The big letters spelling out the name of Arnoux on the marble plaque above the shop seemed to him to be unique and pregnant with meaning, like a sacred writing [grosses de signification, comme une écriture sacrée]" (77/49). The fetishization, which is to say the aestheticization, of the name of the fathercapitalist occurs here through an assimilation of writing to a putatively natural power of (re)production ("pregnancy"). The mother thereby becomes the ground-the "plaque de marbre" - of meaning's inscription. Here, however, the arbitrariness and excess of Frédéric's gesture forms part of the text to be read, as does the relation of his idealizing and reifying focus on the maternal to the other dimensions of the fetish in $L^{\prime} E d u c a t i o n$ sentimentale: the commodity, the artwork, and so on. A full study of gender and desire in $L^{\prime} E d u c a t i o n$ would also want to examine desire's homoerotic circuits, visible here and elaborated elsewhere as Frédéric's charged relations with Arnoux and above all with Deslauriers. See Mary Orr, "Reading the Other: Flaubert's L'Education sentimentale Revisited," French Studies 46.4 (1992): 412-23. 
The fetish, as we saw, includes in its makeup a historical dimension to the extent that it claims to commemorate an event: the event of a promise or contract in the mercantile model, or a trauma in the psychoanalytic one. This commemorative aspect, however, is also paradoxically mobile and uncertain, since the fixing and freezing energies of the fetish generate an equivalent displacement and disintegration. As representations, in other words, fetishes are always inauthentic, above all in their representation of "history." Flaubert famously constructed his "historical" scenes out of preprocessed data-memoirs, newspapaper reports, and so on-in order to tease into blank irony the stereotyped discourse that masquerades as historical truth. Indeed, in his representation of Frédéric's one sustained experience of a dramatic revolutionary event-the sack of the Tuileries on February 24-Flaubert not only draws heavily on "the 'one says' [on dit] of 1848 , as represented in stereotypes," but draws attention to the fetishistic character of verbal stereotypes by recycling sexual ones. ${ }^{35}$ The crowd's "frenzy" in the Tuileries ("An obscene curiosity caused everyone to ransack all the closets, search all the alcoves, and turn out all the drawers. Jailbirds thrust their arms into the princesses' bed, and rolled about on it as a consolation for not being able to rape them" [L'Education, 289/289]) recalls and parodies one of the best-known scenarios in Burke's Reflections on the Revolution in France: "A band of cruel ruffians and assassins . . . rushed into the chamber of the queen, and pierced with an hundred strokes of bayonets and poniards the bed, from whence this persecuted woman had but just time to flee almost naked." 36 Where Burke's rioters are bloodthirsty, Flaubert's jailbirds are always at least faintly ludicrous: in 1848 tragedy occurs as farce, and the revolution's symbols and archetypes-even that of the Medusa herself-have become commodities and clichés, and possess in consequence a ridiculous yet desperate power: "In the entrance hall, standing on a pile of clothes, a prostitute [une fille pudique] was posing as a statue of Liberty, motionless and terrifying, her eyes wide open" (289/290). ${ }^{37}$ Such

35. Herschberg-Pierrot, "Le travail des stéréotypes," 45. As Françoise Gaillard comments, the stereotype may be conceptualized as a "fetishization of thought": see "L'En-signement du réel" in La Production du sens chez Flaubert, 198.

36. Edmund Burke, Reflections on the Revolution in France (Harmondsworth: Penguin, [1790] 1968), 164. The account continues to describe the king and queen being taken from a palace "swimming in blood, polluted by massacre, and strewn with scattered limbs and mutilated carcasses," and marched in a procession "amidst the horrid yells, and shrilling screams, and frantic dances, and infamous contumelies; and all the unutterable abominations of the furies of hell, in the abused shape of the vilest of women" (165).

37. According to P.-G. Casteux, Flaubert: L'Education sentimentale (Paris: Société d'Enseignement Supérieur, 1980), 183-84, Flaubert drew this image from a Histoire de la révolution de 1848 (1850) by Daniel Stern (the pseudonym of Mme d'Agoult). The figure of the Medusa had in fact 
visions are likely to strike us as historical only in the sense in which history can be understood as simply another discourse, another tissue of commonplaces and prescripted tropes, or outlet for ideological representations.

Yet the notion of the fetish as inscription or Denkmal nonetheless offers us the chance to think history in non-ontic fashion. To gain a better sense of this historicity we may, as it were, travel deeper into the heart of the fetish by looking closely at the two major instances in which Frédéric misses history while embroiled in the aporia of his love plot. The first occurs at the beginning of the 1848 Revolution: Frédéric refuses to join his friends in a demonstration on February 22, the first day of revolutionary activity, because of his rendezvous with Mme Arnoux; and because she stands him up, he spends February 23 courting Rosanette, and misses the day of rioting which led to the revolution itself. He thus experiences the "origin" of the revolution as an agony of waiting for the fetish-woman who never arrives, and as a compensatory lateral move in his sentimental education. Later in the year Frédéric misses the proletarian uprising in June-"the most colossal event [Ereignis] in the history of European civil wars" (Marx, Eighteenth Brumaire, 23) - because he and Rosanette have left Paris for a holiday in Fontainebleau. Let me begin by examining the Fontainebleau idyll, which overtly thematizes the fetish's power to romanticize and commodify history.

For the male and middle-class Frédéric, Fontainebleau provides history as erotic nostalgia. As he stands before the painting of Diana in the Banqueting Hall, the "point lumineux" of Mme Arnoux becomes the star-like radiance of Diane de Poitiers:

The most beautiful of these legendary creatures was shown in a painting on the right, in the character of Diana the huntress, and indeed of Diana of the Underworld, no doubt to indicate the power she wielded even beyond the grave. All these symbols confirmed her fame; and something of her still remained there, a faint voice, a lingering splendour [rayonnement].

\footnotetext{
become a charged stereotype of the era: for an analysis of its functioning, see Neil Hertz, "Medusa's Head: Male Hysteria under Political Pressure," in The End of the Line: Essays on Psychoanalysis and the Sublime (New York: Columbia University Press, 1985), 161-215. Drawing on various accounts of 1848 and the Commune in order to comment on "a recurrent turn of mind: the representation of what would seem to be a political threat as if it were a sexual threat," Hertz, following Freud, suggests that the image of Medusa concentrates "a litany of nervous questions": "questions that give expression to epistemological anxiety (can I trust my eyes?), to narcissism (can I hold myself together?), to sexual anxiety (can I hold on to my penis?), to-beyond that-social and economic fears about property and status (can I hold on to anything, including representations of myself?)" (167). The tranformation of such uncertainty into a charged, specular confrontation with sexual difference works to buttress the fetishistic illusion "that one can see history as the features of a face, read it off a composed physiognomy" (179).
} 
Frédéric was seized with an inexpressible feeling of retrospective lust [concupiscence]. (L'Education, 313-14/319-20)

This sharply focused fetishization of the past mutates into Frédéric and Rosanette's literary and touristic consumption of the Fontainebleau forest. Their guide takes them to the famous spots; the narrative voice pursues medieval fantasies in indirect free style ("on pense aux ermites, compagnons des grands cerfs ..."); and the forest acquires the trappings of symbolic meaning: "Some [trees], astonishingly tall, bore themselves like patriarchs or emperors, or, touching each other at the tip, seemed to form triumphal arches with their long trunks; others, grown obliquely from the ground, seemed columns about to fall" $(316 / 323)$. Arrived at this "foret de symboles" we find ourselves at the locus of much interpretative or pseudointerpretative activity, both in the text itself and in the criticism it has inspired. Here the trees are like triumphal arches and falling columns; a little further on they resemble a crowd [foule], while also possessing crowns [couronnes] like the ruler whom the crowd swept away in February. In short, the forest of Fontainebleau, symbol of royal, mystical France, offers itself as a symbolization and naturalization of history; yet as soon as one takes up its offer, of course, one repeats Frédéric's fetishism. History and the love plot entwine here precisely to the extent that one falls into the text's trap. ${ }^{38}$

Nonetheless, it will prove interesting to continue to follow Frédéric and Rosanette into the fetish-forest, since as their tour continues the text's language becomes excessive in a mode difficult-as so often in Flaubert-to pin down. From the unremarkably catachretic "crowns" of the beech trees we are moved through a descriptive catalogue that grows more and more baroque in its tropes: holly bushes seemingly "made of bronze"; birches bent in "elegiac attitudes"; pines "symmetrical as organ-pipes" that "seemed to sing as they swayed continuously to and fro"; finally, "huge

38. For a relatively straightforward reading of the Fontainebleau episode as a naturalization of history, see Brombert, "L'Education sentimentale: Articulations et polyvalence," and his The Novels of Flaubert (Princeton: Princeton University Press, 1966), 177-78; see Brooks for a similar reading, which concludes that the political message of Flaubert's text is quietism (Reading for the Plot, 203-4). Culler's discussion of Fontainebleau, directed against Brombert, emphasizes the text's ironic disqualification of the symbolic reading by noting that the natural analogy-trees that look like emperors or triumphal arches or columns about to fall—cuts two opposing ways: "Is political revolution an act of desecration like chopping down monarchical trees or destroying the Empire's monuments, or does the very posture of trees which look like columns about to fall offer a natural analogue which refutes the former suggestion?" From the first perspective, the natural analogy would underline the "tragic seriousness of political revolution" as an assault on a natural order; from the second, revolution would itself become a natural phenomenon, and the merely human sort would fade into "triviality and insignificance." The text gives us no means to privilege one option over the other: "It is clear that everything can be interpreted," Culler concludes, "but not what is the significance of such interpretations" (Flaubert, 102). 
gnarled oaks" that "rose convulsively out of the ground, embraced one another, and solidly established on their torso-like trunks, threw out their bare arms in desperate appeals and furious threats, like a group of Titans struck motionless in their anger" (316-17/323). The passage hovers between reification and personification, since its tropological progression first swerves in an inanimate direction ("made of bronze"), then employs a technical rather than a natural anthropomorphic vehicle (organ-pipes) before leaping to an Ovidian idiom (the Titans). The twin tropes of fetishism collapse into each other and in doing so become hyperbolic, manifestly rhetorical fictions: it is as though these trees were registering the production of figurative language itself, prior to the establishment of the binary oppositions (animate/inanimate, person/thing) upon which the tropes of personification and reification draw.

It is precisely such an uncanny principle of textual production, I suggest, which drives Flaubert's paragraph toward a climax wickedly balanced between sublimity and irony:

Then they crossed monotonous clearings, planted with saplings here and there. A sound of iron, hard and numerous blows rang out; it was a team of quarrymen striking the rocks on a hillside. These rocks became more and more numerous, finally filling the whole landscape; cube-shaped like houses, or flat like paving-stones, they propped each other up, overhung one another, and merged together like the monstrous, unrecognizable ruins of some vanished city. But the frenzied chaos in which they lay conjured up rather thoughts of volcanoes, floods, great unknown cataclysms. Frédéric said that they had been there since the beginning of the world and would stay like that until its end; Rosanette turned her head away, saying that "it would drive her mad," and went off to pick some heather. $(317 / 323)$

It is easy to interpret these apocalyptic rocks as signs of "the futility of [the revolution of 1848] in relation to geological revolutions" (Brombert, " $L^{\prime} E d u$ cation," 61), and also easy to cast suspicion on that sublime interpretation, which is specifically identified as Frédéric's both in this passage and again, more pointedly, a little later in the episode: "Sometimes they heard the roll of drums far away in the distance. . . .'Why, of course! It's the insurrection!' Frédéric would say with a disdainful pity, for all that excitement struck him as trivial in comparison with their love and eternal Nature" (318/325). Yet this familiar Flaubertian paradox, whereby an interpretation is rendered at once silly and inevitable, does not entirely exhaust the passage's difficulty. We may begin with the simple observation that the scene does not appear to be describing "nature" at all. Prior to "conjuring up" thoughts of volcanoes 
and floods and inspiring Frédéric's sublime commonplace, the rocks are "houses" and "paving-stones" arranged in ways that resemble the "ruins of some vanished city"; whether or not they have gotten that way because "a team of quarrymen" is "striking" them, they record in their figurative shapes the expenditure of labor power. Should one then discover at work in this scene a "political unconscious"? Perhaps; so long as one does not imagine that either the proletarian uprising of the June days or labor in the abstract (i.e., the commodity) is the repressed truth of these rocks: such allegories would finally be as hasty and naturalizing as Frédéric's, if only because the activity of "striking the rocks" (battant les roches) is not even necessarily labor. If it is, it is labor in the sense that writing (in Flaubert's sense) is labor: hard work, no doubt, and productive of marks and sounds, and words and figures, yet work that is as useless as that of the prisoner, who in the French cliché that would be this passage's Riffaterrean hypogram if it had a hypogram, is condemned to break rocks, casser les cailloux. We risk misreading the figurative structure of the passage, however, if we seize too eagerly on the pathos that figures of social injustice provide. Like the prisoner, the "team of quarrymen striking the rocks on a hillside" is engaged in the redundancy of striking rocks so as to produce rocks-but these are not just any old rocks: "These rocks became more and more numerous, finally filling the whole landscape; cube-shaped like houses." This rock-striking produces the rocks upon which the fetish-the fetish of interpretation-stages itself. We may say without the slightest exaggeration that the text is figuring the possibility of its own coming into being.

This allegory of textual production intensifies as Frédéric and Rosanette's close encounter with rocks comes to a climax in the next paragraph, and the silent, solar logos of light itself "strikes" the fetish into phantasmatic life:

One day they climbed half-way up a sand-hill. Its surface, untrodden [vierge de pas], was grooved with symmetrical undulations; here and there, like promontories on the dried-up bed of an ocean, rose rocks which bore a vague resemblance to animals, tortoises thrusting their heads forward, seals crawling along, hippopotamuses, and bears. Not a soul. Not a sound. The sand, struck by the sun, was dazzling [éblouissant]; and all of a sudden, in that quivering of the light, the animals seemed to move. They hurried away, fleeing vertigo [fuyant le vertige], almost panic-stricken. (317/324)

The rochers de Fontainebleau are famous for their shapes: we have certainly not left the circuit of the tourist, nor indeed the orbit of the ridiculous, as 
these tourists, after all, are running away from rocks. ${ }^{39}$ But the text has also moved us into the denatured, erotic, oriental, and pointless world of Saint Antoine, and toward what Jonathan Culler calls Flaubert's notion of the "sacred": that is, "pure form" (Flaubert, 223), "the sentimental purified by irony, emptied of its content, so that it may come to represent in the allegory of interpretation the formal desire for connection and meaning" (226), which is to say a textuality built on "arbitrary meanings guaranteed not by man but by God" (227). We could almost agree with these shrewd characterizations, were it not for the persistent impurity of irony and formal closure in Flaubert. In the vocabulary developed here we may say that the sacred is always also a fetish. Yet Culler's comments respond to a predicament latent within fetishism: the fetish elicits as its condition of possibility a disruptive institution of the signifier which must occur "before" any meaning can guarantee this signifier's legibility. If the production of meaning is the production of the fetish, that institutive act of fetishism itself entails an impossible act of personification (or "reification") prior to the existence of persons or things. The rocks bearing a "vague resemblance" to the exotic animals of the Flaubertian imagination, which "seem to move" when struck by light-by the "éblouissement" that earlier shone out of the eyes of the "apparition" of Mme Arnoux-figure the production of meaning as personification, as the production of "figure" itself out of the uncertainty that is the condition of all signification, and which here leaves its mark as the image of ambiguous marks: a surface "vierge de pas," "rayée en ondulations symmétriques."

We encounter a similar pressure of the inscription within the fetishistic dilemma suffered by Frédéric a few pages earlier in the novel, and a few months earlier in the plot, as he waits for Mme Arnoux at the corner of the Rue Tronchet on February 22, while the first crowds of the revolution gather in the Place de la Concorde. As the hours pass, the strain of waiting causes him to "dissolve in despair":

The echo of his footsteps jarred his brain.

When he saw that his watch said four o'clock he felt a sort of dizziness and panic. He tried to recite some poetry to himself, to do a sum at random, to make up a story. It was impossible! he was obsessed by the image of Madame Arnoux. He longed to run and meet her. But which way should he go so as not to miss her? (277/277-78)

The subject of fetishism here suffers the fragmentation inherent in fetishistic unification, a crisis of the subject which is equally one of narrativeat the Camargo Foundation for their helpful responses to early portions of this chapter. 
Frédéric cannot "make up a story [histoire]" any more than he can choose a direction to run in, for he is pinned by the fictionality of the fetish into the predicament of waiting endlessly for its arrival. The story of his waiting is brought to an end only retrospectively, when a few pages later we learn that "Frédéric had gone home": "He sank in to a kind of sleep; through his nightmare he heard the rain falling, and imagined all the time that he was still out there on the pavement" (279/281).

In between Frédéric's waiting and his dream of waiting, the text tells the story of why Mme Arnoux does not arrive: a story that itself begins as her own dream of waiting:

The night before, she had dreamt that she had been standing for a long time on the pavement in the Rue Tronchet. She was waiting there for something indefinite yet important, and without knowing why, she was afraid of being seen. But a horrible little dog which had taken a dislike to her was worrying the hem of her dress. It kept coming back to her and barked louder and louder. Madame Arnoux awoke. The dog's barking went on. She strained her ears. The noise was coming from her son's bedroom. She rushed into the room in her bare feet. It was the child himself who was coughing. His hands were burning hot, his face red and his voice strangely hoarse. $(278 / 278-79)$

This barking or coughing will later be described as being "like the noise made by the crude devices that make cardboard dogs bark" $(278 / 279)$ : it resembles mechanically produced noises that resemble natural noises, and manifests itself as an impediment to speech: "[The child] seemed to be puffing out his words" (280) ("On aurait dit qu[e l'enfant] soufflait ses paroles" [279]). The cough interrupts Mme Arnoux's dream only to rewrite the dream as reality, transforming the suspension of waiting into a more agonizing vigil:

The hours went by, heavy, dreary, interminable, heartbreaking; and she counted the minutes only by the progression of this death-agony. The spasms of his chest threw him forward as if they were going to break him up; finally he vomited something strange which resembled a tube of parchment. What was it? She supposed that he had thrown up a piece of his bowels. But he was breathing freely and regularly. This apparent improvement frightened her more than anything else; and she was standing there petrified [petrifiée], her arms dangling and her eyes fixed in a stare, when Monsieur Colot arrived. According to him, the child was out of danger. $(279 / 280-81)$ 
If the cough at once interrupts and causes Mme Arnoux's torment of waiting, the cessation of the cough might be said to produce Frédéric's, since Mme Arnoux, interpreting her child's spontaneous cure as a sign from God, offers up her love for Frédéric "as a sacrifice" (281). Flaubert's notes on croup, taken from Trousseau's Clinique médicale, are more prosaic: "It sometimes happens, one time out of six or eight, that, through an act of vomiting or coughing, the larynx clears itself all of a sudden, the child spitting out strips of false membranes [fausses membranes] or membranal tissues coming from the trachea and the glottis." 40 And an interpretation of this scene adequate to its peculiarities will need to be more prosaic still, which is not always to say more self-evident.

We have seen that the fetish is a visual affair: a double-edged gift of blinding vision, brought into focus here as the figure-once again-of the medusal mother, "petrified," "her eyes fixed in a stare." And we have also seen that these paradoxes of vision negotiate a predicament that is not visual but figural. Vision is a hypothesis that can never be guaranteed, no matter how hard the fetish tries; and I suggest we understand the emergence of aural stimuli such as the "sound of iron" in the Fontainebleau scene or little Eugène Arnoux's cough in this one as signals that relay the non-phenomenal inscription of the fetish's phenomenality. Read in this way, these sounds are not actually sounds at all; or, better, they are sounds that record the uninsurable event whereby they are taken as sounds, just as the fetish is taken as a vision ("une apparition"). Speculating on the privilege Freud grants to aural perception in the primal scene, Jean Laplanche and J.-B. Pontalis suggest that "hearing, when it occurs, breaks the con-

40. The note continues: "-at that instant calm descends. The child falls asleep. But often another false membrane forms itself and the sickness begins again." Flaubert's notes are reproduced in the Club de l'Honnête Homme edition, 452-53; they may also be found in Dumesnil, L'Education sentimentale de Gustave Flaubert, 54. According to Dr. Chaume, who was in charge of tracheotomies when Flaubert visited the Hôpital Sainte-Eugénie (now the Hôpital Trousseau) in March of 1868, and who published an account of the visit in the Chronique médicale of 15 December 1900, Flaubert was too squeamish to attend an operation. Dumsenil draws from this episode a rationale for Flaubert's decision to have Mme Arnoux's child cure itself spontaneously; we are seeking here the possibility of a less reductive explanation.

From Trousseau's study Flaubert also, for that matter, acquired the metaphor "a tube of parchment" to describe the false membranes blocking the larynx: "What occurs there," Trousseau writes, "is what occurs if, between the reeds of a clarinet or bassoon, you interpose a bit of wet parchment; and the comparison is all the more exact in that the false membrane can be perfectly well compared to a bit of parchment swollen by humidity. The reed instrument constituted by the larynx thus no longer works." A. Trousseau, Clinique médicale de l'Hôtel-Dieu de Paris, 2 vols. (Paris: J.-B. Baillière et Fils, 1861), 1:320-21. Trousseau is drawn to the pathos of the loss of voice engendered by the croup, and goes on at some length about the sound of the cough, the tone of any surviving voice, and so on. Flaubert's notes are taken from pages 319-23 of this volume. Flaubert's comment that the relatively rare spontaneous cure for the croup often results in the growth of more membranous tissue, however, runs slightly counter to his source: Trousseau emphasizes that the spontaneous ejection of false membrane actually results in a better rate of cure than the tracheotomy does (323). 
tinuity of an undifferentiated perceptual field and at the same time is a sign (the noise waited for and heard in the night), which puts the subject in the position of having to answer to something." 41 Laplanche and Pontalis are working through the psychoanalytic version of the paradox of the constitutive event. The trauma of sexuality produces the subject, which must nonetheless preexist this event in order to experience it, and which consequently internalizes sexuality belatedly, as a repetition always already in place. The "sound" of the primal scene is the call of the signifier: an inaudible call which cannot be guaranteed by any intention, yet which is "heard" as intentional by the subject it constitutes or interpellates. This call echoes in Eugène's cough as a mechanical resistance to voice, and as a near-shattering force ("the spasms of his chest threw him forward as if they were going to break him up"); it inhabits the "striking" of the rocks at Fontainebleau as the doubleness of a sound at once singular ("un bruit de fer") and iterative ("des coups drus et nombreux").

One could thus say that Eugène coughs up the signifier's residue. The "something" which resembles "a tube of parchment" suggests the materiality of an event inaccessible to experience-a "sublime object of ideology," in Slavoj Žižek's phrase: that is, "a positive, material object elevated to the status of the impossible Thing." 42 Žižek's Lacanian terminology of the "real," however, lends a misleading substantiality to this diseased, vomited remainder, or excess of voice. As the residue of the signifier, these "false membranes" are neither real nor unreal, just as they are neither organic nor inorganic. The materiality of the signifier is the condition of the difference between dream and reality, or more generally between figure and ground. It is the blow of an event which has no singularity apart from its repetition, yet which is iterable only as the trauma of a radical, unanswerable singularity. And we may note at this juncture that the cough of the child continues to echo as the second volume of the novel closes. Wending their way back from a restaurant-the Trois Frères provençaux, where Flaubert and Maxime du Camp were also eating, that night of 23 FebruaryFrédéric and Rosanette hear "a crackling noise behind them like the sound of a huge piece of silk being ripped in two. It was the fusillade on the Boulevard des Capucines." At the house in the Rue Tronchet which Frédéric had prepared for Mme Arnoux, and where he now takes Rosanette, the chapter closes with a final invocation of uncertain sounds: "About one

41. Jean Laplanche and J.-B. Pontalis, "Fantasy and the Origins of Sexuality," The International Journal of Psycho-Analysis 49.1 (1968): 10-11. At this point in Laplanche and Pontalis's argument the most immediate reference is to "A Case of Paranoia" (1915), in which Freud describes the case of a woman patient whose fears were at once visual and aural: she felt she was being watched and photographed while lying with her lover, and claimed to have heard a "noise," the click of a camera.

42. Slavoj Žižek, The Sublime Object of Ideology (London: Verso, 1989), 71. 
o'clock [Rosanette] was awoken by distant rumblings; and she saw him sobbing with his head buried in the pillow." To her query Frédéric explains that he is crying out of an "excess of happiness": "I've been wanting you too long!" $(282 / 283)$. The blows on the rocks and distant roll of drums in the Fontainebleau scene, the repercussion of Frédéric's waiting feet, the bark of a dog, the cough of a child, the crackling of a fusillade, the "distant rumblings" and the gentleman's sob, mark the trace of a violence prior to and yet of signification; and we may say that these marks inscribe an allegory of history in the heart of the love-plot, at the point of love's nonconsummation.

Why history? Because history remains the best name we can give to the excess, the radical exteriority, of an event in relation to meaning, knowledge, or desire. The thought of history always appeals at a certain point to referential force: we say, when pressed, that history is what happened, what really happened-"what hurts," in Fredric Jameson's somewhat wishful epigram, which hustles the referential difficulty of "what really happened" a little too quickly into the subjective certainty of pain. But one could venture the formulation that history is pain that cannot be experienced. Flaubert's focus on trauma responds to the historical novel's conceit that history can be captured as narrative, which is an ambition latent in all aesthetic narrative. Indeed, the deepest motivation of aesthetics is discoverable in its attempt to gather the referential insistence of "history" into the totality of consciousness or form. In its critical displacement of this project, L'Education sentimentale rewrites Bildung as the making, factio, of a feitiço, a fetish, and suggests that the subject "experiences" history as an inexplicable interruption, or the fragmenting anguish of intolerable boredom. From the subject's perspective, history can only be enountered as trauma: as the "parole soufflée" of an occurrence that arrives too early or too late for the consciousness it makes possible. ${ }^{43}$

43. See Jacques Derrida, "La parole soufflée," in Writing and Difference, trans. Alan Bass (Chicago: University of Chicago Press, 1978), 169-95, for a meditation on the "parole soufflée" - the word whispered, prompted, spirited away-of a "historicity long since eliminated from thought" (170), the impossible "ground" of metaphysical differences (174): "Which amounts to acknowledging the autonomy of the signifier as the letter's historicity; before me, the signifier on its own says more than I believe that I meant to say, and in relation to it, my meaning-to-say is submissive rather than active" (178). For an exploration of the relation between history and trauma, see Cathy Caruth, "Unclaimed Experience: Trauma and the Possibility of History," Yale French Studies 79 (1991): 181-92: "The historical power of the trauma is not just that the experience is repeated after its forgetting, but that it is only in and through its inherent forgetting that it is first experienced at all. . . . For history to be a history of trauma 
Suspended between futurity and anteriority, the historical event, in $L^{\prime} E d-$ ucation sentimentale, becomes the aporetic narrative of love. Love tells the deconstructive story of its own inability to catch up with itself: it cannot know what it does, or do what it knows, precisely because its origins and mode of existence are historical. Love's literariness-that is, its dissymmetrical affirmation and destruction of itself as fiction-is in fact its historicity: love occurs, as an event that cannot be present to itself. The event of love manifests itself as fetishism, and the paradox of love plays itself out as a tension between the production and dispersal of identity and meaning in and as the fetish. And the subject that finds its possibility in the fetishization of love's aporia is indeed the subject "of history" — which means that it is in fact possible to think the scriptive force of history as "labor," so long as one specifies that the historicity of labor power resides not in labor's dialectical negation of the real, but in its opacity to its own intention, and its excess over any system of calculation and distribution.

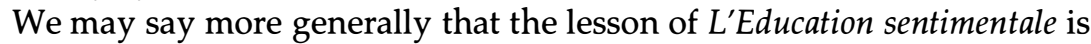
that history is the production of a text. One should not rush toward the comfort of declaring such an insight idealist or bourgeois. Marx's comments at the beginning of the Eighteenth Brumaire refer us to a linguistic example precisely in order to declare history irreducible to consciousness:

Men make their own history, but they do not make it just as they please; they do not make it under circumstances chosen by themselves, but under circumstances directly encountered, given and transmitted from the past. The tradition of all the dead generations weighs like a nightmare on the brain of the living. And just when they seem engaged in revolutionizing themselves and things, in creating something that has never yet existed, precisely in such periods of revolutionary crisis they anxiously conjure up the spirits [Geister] of the past to their service and borrow from them names, battle cries and costumes in order to present the new scene of world history in this time-honored disguise and this borrowed language. ... In like manner a beginner who has learnt a new language always translates it back into his mother tongue, but he has assimilated the spirit [Geist] of the new language and can freely express himself in it only when he finds his way in it without recalling the old and forgets his native tongue in the use of the new. (Eighteenth Brumaire, 15-16)

Just when we think we are breaking with the past we are most haunted by it; we begin to speak the language of the new only insofar as we "forget" the

means that it is referential precisely to the extent that it is not fully perceived as it occurs; or to put it somewhat differently, that a history can be grasped only in the very inaccessibility of its occurrence" (187). 
"mother tongue" of our own identity, which is to say that revolution occurs only in the eclipse of revolutionary consciousness. There is more empirical plausibility to such a paradox than might immediately meet the eye. It is not simply the complexity of causal relations that leads Franz Fanon to ascribe a certain randomness to the revolutionary event: "[I]n these circumstances the guns go off by themselves, for nerves are jangled, fear reigns and everyone is trigger-happy. . . . It must be remarked here that the political parties have not called for armed insurrection, and have made no preparations for such an insurrection. All these repressive measures, all those actions which are a result of fear are not within the leader's intentions: they are overtaken by events." 44 So far as we know, the massacre on the Boulevard des Capucines toward which Frédéric is so indifferent, which left some hundred or so dead and helped precipitate Louis Philippe's fall, occurred without any officer giving an order to fire; and the touch of personification in Fanon's figure of the guns "going off by themselves" resembles the tropes Flaubert scatters in his account of the February events: "[T]he insurrection organized itself powerfully, as if it were directed by a single hand" (L'Education, 285/286); "of itself, without upheaval, the monarchy was melting in a rapid dissolution" $(286 / 286)$. The point is not that revolutions do not have causes; it is rather that as events they exceed causal explanation. As François Furet remarks of another, more revolutionary revolution, "[T]he mere fact that the [French] Revolution had causes does not mean that they are all there is to its history. . . [T] [Te revolutionary event, from the very outset, totally transformed the existing situation and created a new mode of historical action that was not intrinsically a part of that situation." 45 Revolution, seemingly the moment in which history offers itself to experience, is in fact the moment of a rupture irreducible to causality or intentionality. If we understand literariness as a term for such constitutive moments of rupture, we arrive at the seeming paradox that history is literary history. The ideological or fetishistic recuperation of history in turn becomes understandable as the obsession with plot which Furet ascribes to "revolutionary consciousness" (53), and which Flaubert deploys as the literary conventions of the Balzacian novel.

We may observe in conclusion that to say that history is "literary" in this sense is to say that it is always potentially revolutionary. A certain sense of loss or wreckage clings to such insights: one thinks of Benjamin's assertion that allegory writes history "on the countenance of nature in the characters

44. Franz Fanon, The Wretched of the Earth, trans. Constance Farrington (New York:Grove Press, 1963), 56-57.

45. François Furet, Interpreting the French Revolution, trans. Elborg Forster (Cambridge: Cambridge University Press, 1981), 22. Furet also comments that "[ $t]$ he Revolution is the gap that opened between the language of the Cahiers [de doléances, the list of grievances submitted to Louis XVI] and that of [Marat's] Ami du peuple in the space of only a few months [in 1789]" (46). 
of transience," and in the form of "ruin" and "irresistible decay." 46 But the loss which allegory mourns as history is not reducible to pathos. It bears a greater affinity to the "unanticipatable alterity" which Jacques Derrida affirms as the "democratic promise" of communism, for instance, than it does to the kinds of pain we are able to integrate as subjectivity or process as aesthetic pleasure. ${ }^{47}$ Flaubert is not the sort of author one would normally want to think of as engagé; nor is L'Education sentimentale a text that offers much in the way of purchase for even the most nuanced utopianism. Yet this text's-and this author's-uncompromising literary vocation bears a curious similarity to the "rumeur continue" of the crowd which renders Frédéric fatigued and dizzy (100/75); and perhaps, if one bends one's ear far enough, it will become possible to hear in that impersonal murmur an affirmation of the event-always, necessarily, the revolutionary event-of the other: an affirmation indistinguishable from a loss which the phallocentric and aesthetic negativity of Bildung can only record and mourn without knowing it. If one were to win that interpretative gamble it would become possible to say that, in telling the story of the Bildungsroman's ruin, Flaubert novelizes, betrays, and commemorates the irreplaceable alterity of the other as the apparition of love.

46. Walter Benjamin, Origin of German Tragic Drama, trans. John Osborne (London: New Left Books, 1977), 178. Though the melancholia Benjamin ascribes to allegory does not match the tone of Flaubert's denatured prose, Benjamin's formulations otherwise address the landscapes Flaubert constructs in the Fontainebleau episode; e.g.: "[I]n allegory the observer is confronted with the facies hippocratica of history as a petrified, primordial landscape" (166).

47. Derrida, Spectres de Marx, 111. In the context of a reading of $L^{\prime} E d u c a t i o n$ sentimentale it is interesting to note the similarity between Marx's description of the non-revolution of 1848 ("when only the ghost [Gespenst] of the old revolution walked about [ging um]" [Eighteenth Brumaire, 17]) and Marx and Engels's famous claim that "[a] specter [Gespenst] walks about [geht um] in Europe-the specter of communism" (Karl Marx and Friedrich Engels, "Manifest der Kommunistischen Partei," in Werke, 4: 461). See Derrida, Spectres de Marx, for a study of the complex temporality and wide figurative range of the specter in Marx's writings.

For meditations on the promise of the communal similar in spirit to Derrida's, see Maurice Blanchot, La Communauté inavouable (Paris: Minuit, 1983), and Jean-Luc Nancy, "La Communauté désoeuvrée," in Aléa 4 (1983): 11-49. From this perspective it is possible to read Flaubert's comment that "the crowd has never pleased me except during the days of riot" as more than throwaway cynicism or misanthropic conservatism-attitudes Flaubert was obviously capable of striking both in his writing and his life, particularly the latter. See Flaubert to Louise Colet, 31 March 1853, in Correspondance, 1850-1859 (Paris: Club de l'Honnête Homme, 1971-75), 8:320. 